\title{
The Fifty-Year Old History of American Eastern Medicine and Its Future
}

\author{
Michael G. Lee* \\ American Integrative Medicine Institute, Los Angeles, CA, USA
}

Received October 11, 2021

Revised October 13, 2021

Accepted October 13, 2021

\author{
*Corresponding Author \\ Michael G. Lee \\ American Integrative Medicine Institute, \\ Davis Law Building, 2960 Wilshire Blvd \\ \#330, Los Angeles, CA 90010, USA \\ Tel: +1-213-800-3773 \\ E-mail: michael@aiminet.org
}

Acupuncture in the United States was known as TCM (Traditional Chinese Medicine) 50 years ago. Now, it has grown as American Acupuncture and its role in comprehensive medical therapy is increasing. The future growth in the next few years will be revolutionary compared to the development in the last 50 years. There are only about 30 states that have acupuncture licensing programs and there are only 52 acupuncture education programs producing about 1,500 acupuncturists. These are some concerns that can limit the growth of acupuncture. If American Acupuncture can provide a "low cost, high efficient" patient-centered medicine as part of comprehensive medical care, then we can expect it to produce a big change in medical policy in the United States.

Keywords: Acupuncture, Acupotomy, Eastern medicine
American Eastern Medicine began in 1969 with Acupuncture education by the Sino-American Medical Rehabilitation Association (Samra University). Then Nevada became the first state to implement an Acupuncture licensing program to begin a half-century history.

Acupuncture is widely known as TCM (Traditional Chinese Medicine), but after 2014 Acupuncture and Herbs have been divided and now as evidence-based medicine, Eastern Medicine is commonly better known as Acupuncture. Herb is considered not as a medicine but as a food supplement and is used in a wide variety of fields.

\section{ACUPUNCTURE IN AMERICAN MEDICAL SYSTEM}

The breakdown in the American medical system was demonstrated by the opioid abuse epidemic. In 2017, FDA recommended HCP's (Health Care Providers) Involved in the Management or Support of Patients with Pain (Draft Revision) to use Acupuncture and Chiropractic as an alternative to opioid-based pain-relief drugs

According to a clinical research presentation on Acupuncture at the "Breast Cancer Symposium" sponsored by the American Association for Cancer Research according to FDA guideline in December 2017, of the eleven cancer centers in the United States, 226 breast cancer patients received acupuncture treatment that resulted in significant pain relief (presented on December 7, 2017, at the San Antonio Breast Cancer Symposium in Texas).

Based on such a clinical research study, the editor of the Journal Pain Medicine stated that Acupuncture causes neurophysiological change related to pain. Therefore Acupuncture is a reasonable alternative to opioids and it should be included in mainstream medical care. He stated, "That's why we need to bring it in."

Also, the American medical system is known to be expensive with low efficiency. According to the experts based on statistics, they predict American medical expenditure in 2025 will be $20 \%$ of the GDP. In midst of this, Acupuncture can be expected to produce high efficiency with low cost, therefore possibly taking a bigger role in he mainstream medicine. 


\section{VARIOUS DEVELOPMENT IN ACUPUNCTURE}

Acupuncture is an evidence-based medicine recognized by $\mathrm{NIH}$ that can be utilized together with e conventional medicine. Acupuncture is not only for Acupuncturists, but according to the recommendation by the FDA guideline, all medical providers can use Acupuncture as an alternative to opioid use as its utility is expanding.

There are approximately 35,000 Acupuncturists, Medical Acupuncturists who are MDs holding acupuncture licenses are approximately 12,000, and Physical Therapists practicing Dry Needling are approximately 280,000. Through national Franchise Acupuncture Clinic and Acupuncture clinics with massage expanding in the United States, Acupuncture is seeing rapid growth.

The current state of RSN Acupuncture (Jung Chim) representative of modern applied acupuncture, Acupuncture Point Injection, and Dry Needling are as follows.

- Acupotomy (RSN Acupuncture) are the most comprehensive and unique needling systems to treat and correct musculoskeletal conditions.

AIMI (American Integrative Medicine Institute) introduced America to Acupotomy, also known as "Jung Chim" associated with The Society of Korean Medicine (Founder, Myung Seok Ryu, Ph.D., KMD) in 2016 through clinical education.

RSN Acupuncture is a systemic acupuncture therapy developed by Dr. Myung Seok Ryu, that treats structural and functional damage holistically through acupuncture and acupotomy. RSN Acupuncture treats using micro needling without excision based on human anatomy and physiology, and soft tissue and acupotomy medical therapy.

In midst of this, there is another Acupotomy treatment method called Dao Needle Therapy that sprung up in 2019 by another organization that is very active.

- Acupuncture Point Injection Therapy began in 2001 and is utilized by Acupuncturists as well as all medical providers allowed to practice injection therapy and is being used in a variety of fields. It is especially effective in difficult to treat conditions, musculoskel- etal conditions, sports medicine, and cosmetic fields evidenced by clinical research studies. It is now being practiced by Acupuncturists in ten states in the US.

However, medical doctors try to warn that, "Biopuncture is not related to acupuncture, but it's a great treatment for your nagging muscle or joint issue," according to rehabilitation medical journal.

The actual clinical application of biopuncture utilizes collagen or vitamins, because receiving approval of herbal medicine for injection is difficult. Therefore, homeopathic medication is often utilized.

- Dry Needling being included in Physical Therapists' scope of practice in 2018 became an issue in California. However, Dry Needling is utilized by PTs in many states, and in 2017 state of Virginia held public hearings on it.

Physical Therapists state that Dry Needling is based on neurological and musculoskeletal theory, different from acupuncture meridian theory. Therefore PTs state that Dry Needling is a unique needle therapy separate from acupuncture.

Acupuncture in the United States is expanding to all different medical fields with development in different terminologies and is growing and going beyond the boundaries of Acupuncturists.

\section{THE FUTURE OF MEDICINE}

In 2019, National Geographic wrote in its special article, "The Future of Medicine," "3D print, genetic medicine, and Chinese Medicine" is creating a revolution in medicine through new technology and traditional medicine.

Acupuncture is receiving attention from the American medical system and its status is changing. As the acupuncture educational system is changing and the clinical operation model improves, the Asians who were the main interested group representing Acupuncture are now suddenly changing.

Also, the American medical system is known to be very expensive yet inefficient. As the elderly population is increasing, treatment of geriatric medicine requires a more efficient medical program.

In treating difficult diseases, Acupuncture therapy and its comprehensive approach have a bright future, 
and especially in cancer therapy, acupuncture provides an excellent alternative in improving quality of life.

In order to alleviate side effects from cancer therapy with a patient-centered approach, Acupuncture and Herbal Supplements are requested by many patients. Therefore, $60 \%$ of NCI (National Cancer Institute) designated 45 Comprehensive Tumor Center is now providing acupuncture therapy.

Also in 2021 CMS (Centers for Medicare \& Medicaid Services) approved a Clover Care Health Plan in the United States western region, that provides unlimited acupuncture therapy, herbal supplements, cupping, moxa, tuina, and gua sha. This program is receiving positive feedback from patients looking for acupuncture therapy. Insurance coverage for acupuncture is expected to grow in 2022 .

\section{CONCLUSION}

Acupuncture in the United States was known as TCM (Traditional Chinese Medicine) 50 years ago. Now, it has grown as American Acupuncture and its role in comprehensive medical therapy is increasing. The future growth in the next few years will be revolutionary compared to the development in the last 50 years.

There are only about 30 states that have acupuncture licensing programs and there are only $52 \mathrm{acu}-$ puncture education programs producing about 1,500 acupuncturists. These are some concerns that can limit the growth of acupuncture.

If American Acupuncture can provide a "low cost, high efficient" patient-centered medicine as part of comprehensive medical care, then we can expect it to produce a big change in medical policy in the United States.

*Michael G. Lee, PhD is the founder of AIMI (American Integrative Medicine Institute) holding members from 15 countries, 25 states in the US, 127 cities, 1,875 acupuncturists (753 clinics), operating AIMI network from Los Angeles, USA. 


\section{미국 Eastern Medicine의 50년 역사와 미래}

\section{Michael G. Lee}

American Integrative Medicine Institute, Los Angeles, CA, USA
미국의 Eastern Medicine은 1969년 Sino-American

Medical Rehabilitation Association (Samra University) Eastern Medicine 교육을 시작하여 1972년 Nevada 주가 처 음으로 Acupuncturist 제도를 시행하여 반세기의 역사가 되 었다.

미국에서 한의학은 TCM (Traditional Chinese Medicine)으로 통칭되었으나 2014년을 지나면서 침과 약이 분리 되어 현재는 통합 의학적 근거로 Eastern Medicine에서의 치 료는 Acupuncture로 일반화 되었으며, 한약은 보조요법으로 다양한 분야에서 활용되고 있다.

\section{미국 의료제도에서 ACUPUNCTURE}

미국의 무너진 의료시스템의 경고는 재난 수준의 opioid 남용에서 나타났다. 급기야 2017년 FDA은 HCP's (Health Care Providers) Involved in the Management or Support of Patients with Pain (Draft Revisions)에서 마약성진 통제(opioid-based pain-relief drug) 대안으로 Acupuncture와 Chiropractic를 제안하였다.

2017년 12월 FDA guideline에 의해 실시된 임상연구 결 과를 American Association for Cancer Research (AACR) 등에서 주관하는 "Breast Cancer Symposium"에서 발표한 Acupuncture 시술 결과를 보면, 미국 전역의 11 개 암 센터에 서 226명의 유방암 환자를 대상으로 침술을 시행 한 결과 통 증이 현저히 감소되었다고 발표하였다(presented on $7 \mathrm{De}-$ cember at the San Antonio Breast Cancer Symposium in Texas).

이와 같은 임상결과에 대해 Journal Pain Medicine의 편 집장은 Acupuncture는 통증과 관련된 신경생리학적 변화 (neurophysiological change)를 일으킨다. 그러므로 Acupuncture는 opioid의 합리적인 대안이 될 수 있으므로 $\mathrm{Acu}-$ puncture를 mainstream medical care에 포함하여야 한다고 주장을 하였다. He says. "That's why we need to bring it in."

또한 미국의 의료문제는 고비용 저효율로 나타난다, 통계에 의하면 미국의 의료비용은 2025년 GDP의 약 $20 \%$ 에 이를 것 으로 전문가들은 예측하고 있다. 이런 가운데 '저비용 고효율 "을 기대할 수 있는 Acupuncture은 점차 주류 의료권에서 역 할이 점차 증가 될 것으로 예상된다.

\section{다양하게 발전하는 ACUPUNCTURE}

Acupuncture는 Conventional medicine과 함께 적용 할 수 있는 근거 있는 의학으로 $\mathrm{NIH}$ 에서 인정하고 있다. 따라 서 Acupuncture는 Acupuncturist만의 분야가 아니라 FDA guideline의 권고에 따라 모든 의료인에게 Opioid 대안으로 Acupuncture는 활용 범위가 넓어지고 있다.

현재 미국에는 Acupuncturist 약 35,000명, $\mathrm{MD}$ 로서 침 시술을 할 수 있는 Medical Acupuncturist 약 12,000명, Dry Needling의 Physical therapist 약 280,000명으로 추 산되고 있다. 그리고 전국 규모의 Franchise Acupuncture Clinic, Massage와 combine된 Acupuncture clinic 등 한 의업계에 새로운 환경이 만들어지면서 급속한 발전을 하고 있 다.

미국에서 대표적인 현대응용침법인 RSN Acupuncture (정 침), Acupuncture Point Injection (약침), Dry Needling (건 침)의 현황은 다음과 같다.

- Acupotomy (도침. 정침, RSN Acupuncture)은 The Most Comprehensive and Unique Needling System To Treat and Correct Musculoskeletal Conditions으로 활용 되고 있다.

미국에서 Acupotomy는 AIMI (American Integrative Medicine Institute)에 의해 2016년부터 한국의 대표적인 The Society of Korean Medicine (Founder, Myung Seok Ryu, PhD, KMD)의 'Jung Chim'을 소개하고 임상교육을 통 해 널리 알려졌다.

RSN Acupuncture은 유명석 원장이 체계화한 침구치료법 으로, 인체에 대한 해부학적 지식과 생리학적 이해를 바탕으 로, 연부조직외과학과 침도의학의 진단과 치료 이론에 기반하 여, 인체의 구조적 및 기능적 손상을 침과 침도를 이용하여 비 절개, 미세 침습적 치료 방법으로 직접적으로 온전하게 치료하 는 치료법이다.

이런 가운데 2019년부터는 Dao Needle Therapy라는 또 다른 Acupotomy 치료법을 내세운 단체가 활발하게 활동하고 있다.

- Acupuncture Point Injection Therapy (약침)은 2001년부터 시작되어 Acupuncturist뿐만 아니라 injection therapy를 활용할 수 있는 의료인들에 의해 다양한 분야에서 
발전하고 있다. 특히 난치병, 근골격계 질환 및 스포츠 손상, 미용분야 등에서 탁월한 효과를 나타내는 임상사례가 발표되 면서 미국 내 10여개 주에서 Acupuncturist들에게도 허용되 고 있다.

그러나 $\mathrm{MD}$ 들은 약침을 “근골격계 치료에 효과가 좋은 약침 은 기존 침과 관련이 없다”고 재활의학 Journal에서 주장하면 서 이를 경계하기도 한다.

최근 약침의 임상활용 경향은 치료 목적보다 콜라겐, 비타 민 등을 활용하는 경우가 많다. 이는 약침에 사용하는 약물이 한약을 기반으로 개발 및 허가 받기가 어렵다 보니 동종요법 약물 등을 활용하기 때문이다.

- Dry Needling이 2018년 California에서 물리치료사의 치료범위에 포함하는 것에 대한 문제가 Acupuncturist들에게 대두 되었다. 그러나 이미 2017년 Virginia에서 공청회가 열 리는 등 대부분이 주에서 Dry Needling을 허용되고 있는 추 세이다.

Dry Needling을 활용하는 물리치료사는 기존의 경락이론 중심의 침 치료와 달리 신경계 및 근골격계 이론을 중심이기 때문에 기존의 Acupuncture와는 다른 독창적인 침 치료 라고 주장하고 있다.

이와 같이 미국에서 Eastern Medicine은 Acupuncture를 중심으로 의료 전 영역에서 발전하는 만큼 용어나 호칭이 다양 해지면서 고유의 한의학적 치료가 Acupuncturist만의 영역을 벗어나고 있는 실정이다.

\section{미국에서 EASTERN MEDICINE의 미래}

2019년 National Geographic 특집기사 'The Future of Medicine'에서 '3D Print', '유전공학'과 함께 전통한의학 (Chinese Medicine)이 '새로운 기술과 전통적인 치료법으로 의학계에 혁신을 일으키고 있다고 설명하고 있다.

미국 의료계에서 주목받는 Acupuncture도 의료제도에서 위상이 변화하고, 교육제도가 변경되고, Clinic 경영방법이 새 로워지면서 불변일 것 같던 Eastern Medicine의 기득권 주체 가 순식간에 뒤바뀌어 가고 있다.

또한 미국의 의료 환경은 환자의 만족도는 낮고 비용이 높 은 '고비용 저효율'이 점점 증가되고 있다. 특히 노령화 사회를 맞아 노인성 질환의 경우 '고비용 저효율'이 더욱 심화된 가운 데 효율적인 program 등이 제시되고 있다.
이런 가운데 난치질환 치료의 통합의학적 관점에서 한의학 치료가 더욱 기대되고 있으며 특히 암 치료에 있어서 삶의 질 을 중시하는 치료방안으로 한의학적 치료를 적극 도입 하고 있 다.

특히 효과적인 환자중심치료를 위해 항암치료 부작용 완화 를 위한 'Acupuncture \& Herbal Supplements'는 환자의 요 구에 따라 점차 확대되어 NCI (National Cancer Institute) 지정 45 개 통합종양센터의 $60 \%$ 에서 한의학적 치료를 제공하 고 있다.

또한 2021년 미 정부 CMS (Centers for Medicare \& Medicaid Service)에서 인가되어 시범적으로 미 서부지역에 서 시행되고 있는 Clover Care Health Plan은 침 치료 무 제한' 뿐만 아니라 Herbal Supplement, Cupping, Moxa, Tuina, Gua sha 등을 포함하고 있어서 통합의학적 치료를 원 하는 환자들에게 각광을 받고 있다. 2022년에는 보험 혜택이 확대되어 앞으로 더욱 기대되고 있다.

\section{결론}

미국 Eastern Medicine 그리고 통합의학은 50여년전 TCM (Traditional Chinese Medicine)에서 이젠 American Acupuncture로서 발전되면서 통합의학적 관점에서 역할이 점차 증대되고 있으므로 미국 통합의학은 지난 50년간의 발전 보다 앞으로 수년 내에 획기적인 발전이 있을 것을 예상한다.

이와 같은 기대를 하고 있는 현실은 30 여개 정도에서 Acupuncturist제도가 정착되어 있고, 교육기관도 52개에 불과하 여 연간 Acupuncturist를 1,500여명 배출하다보니 기대되는 발전에 부합하기 어려운 현실도 있다.

그러나 미국 한의학은 통합의학적 관점에서 의료 산업적 기 준보다 환자 중심의 의료서비스로서 '저비용 고효율'의 가치를 실현할 수 있다면 의료 정책에서 커다란 변화를 기대 할 수 있 을 것이다.

*Michael G. Lee, PhD는 AIMI (American Integrative Medicine Institute) 설립자로서 전 세계 15 개국, 미국 25 개 주 127 개 도시 한인Acupuncturist 1,875명(735개 clinic)이 멤버로 참여하는 AIMI network을 미국 Los Angeles에서 운 영하고 있다. 